\title{
Signifyin(g): Ancestral Roots and Black Vernacular in August Wilson's Seven Guitars
}

\section{Karveh EJ}

Department of English Language and Literature, Sobh-e-Sadegh University, Isfahan, Iran

*Corresponding author: Karveh EJ, Department of English Language and Literature, Sobh-e-Sadegh University, Isfahan, Iran, Tel: 0311 23519947; E-mail: ele.srk@gmail.com

Received date: November 07, 2016; Accepted date: December 22, 2016; Published date: December 28, 2016

Copyright: (c) 2016 Karveh EJ. This is an open-access article distributed under the terms of the Creative Commons Attribution License, which permits unrestricted use, distribution, and reproduction in any medium, provided the original author and source are credited.

\begin{abstract}
As of all African-American literature, August Wilson's century cycle plays are of significance concerning AfricanAmerican vernacular. After emancipation, the continued subordination of Blacks represented as an inferior race was justified by the denigration of central characteristics of Black identity such as language. The double-consciousness of the African-American, as mentioned by W.E. DuBois, has brought about differences not only in the social lives of the African-Americans but also in their use of the English language. Seven Guitars is a play in which the interactions between the characters and their language is particularly noticeable. Among the well-known scholars in the field of African-American Literature, Henry Louis Gates is celebrated for his in-depth research concerning African-American Literature, specifically its origins and ancestral connections. Gates posits that the African-American dialect has its roots in ancestral backgrounds. This paper aims to highlight the figuration of everyday language of AfricanAmericans in Seven Guitars and the ways it brings out the personality of each character with emphasis on the work of Gates. It also brings forth the eminent role of ancestral roots and heritage underlying the lives of AfricanAmericans.
\end{abstract}

Keywords: August Wilson's seven guitars; Language; Signifyin(g) monkey; Ancestral roots; Black vernacular; Mythology

\section{Introduction}

Gates has been called "the most visible and influential present-day American humanist". His own writings, as well as his discovery and authentication of the historically significant writings of others, have catapulted him into a limelight seldom experienced by academics. Gates' fascination with black literary theory has centered on language. In Figures in Black: Words, Signs and the Racial Self, he writes: "For it is language, the black language of black texts that expresses the distinctive quality of our literary tradition" [1]. Gates traces the origin of the Signifying Monkey in Black culture and vernacular. He explains,

Tales of the Signifying Monkey had their origins in slavery. Hundreds of these have been recorded since the nineteenth century. In black music, Jazz Gillum, Count Basie, Oscar Peterson, Oscar Browne, Jr. Little Willie Dixon, Nat "King" Cole, Otis Redding, Wilson Picket, and Johnny Otis-at least-have recorded songs called either "The Signifying Monkey" or simply "Signifyin(g)." My theory of interpretation, arrived at from within the black cultural matrix, is a theory of formal revisionism, it is tropological, it is often characterized by pastiche, and, most crucially, it turns on repetition of formal structures and their differences (Gates).

Gates asserts that the Signifying Monkey dates back to Yoruba Mythology as a trickster figure, a figure that imitates and parodies, lies and cajoles others. In general, he sees this idea of signification as a theory of reading that arises from Afro-American culture. His aim in this regard is to decode the signs in the If an oracle still popular among the Yoruba in Nigeria. Gates sees the signifying monkey as, "he who dwells at the margins of discourse, ever punning, ever troping, ever embodying the ambiguities of language - is our trope for repetition and revision, indeed our trope of chiasmus itself, repeating and reversing simultaneously as he does in one deft discursive act" (Gates). Gates starts his discussion by defining signification in black discourse as a mode of figuration. Signifying is deemed a rhetorical trope which in black discourse is represented by actions such as marking, loudtalking, testifying, calling out (of one's name), sounding, rapping, playing the dozens, and so on (Gates). Gates then moves onto Abraham's definition of signifying:

Signifying seems to be a Negro term, in use if not in origin. It can mean any of a number of things; in the case of the toast about the signifying monkey, it certainly refers to the trickster's ability to talk with great innuendo, to carp, cajole, needle, and lie. It can mean in other instances the propensity to talk around a subject, never quite coming to the point. It can mean making fun of a person or situation. Also it can denote speaking with the hands and eyes, and in this respect encompasses a whole complex of expressions and gestures. Thus it is signifying to stir up a fight between neighbors by telling stories; it is signifying to make fun of a policeman by parodying his motions behind his back; it is signifying to ask for a piece of cake by saying, "my brother needs a piece of cake" (Gates).

Abrams believes signifying to be an indirect argument or persuasion, a language of implication. Examples of such signifying processes can be found in all of Wilson's plays. His attentiveness in listening to black folks has given him the natural dialogues he employs. In these dialogues we understand the indirectness of black vernacular. Referring to something but wanting to mean another. Moreover, the repetitive characteristic of signifying can be detected in his characters. A close example would be Hambone's repetitive phrase of "He gonna give me my ham, he gonna give me my ham" in Two Trains Running $[2,3]$. 
Page 2 of 4

Timothy Robinson notes the influence of oral tradition in terms of signifying:

In order to fully understand the nature of signifying in African American literature, one must recognize the impact of the oral tradition within African American culture. Verbal signifying refers to the art of taking recognizable words or phrases and giving these words new meanings with the intent of asserting a point of view through innuendo or indirection. In some instances, a speaker might signify in order to criticize or put down an individual or group; at other times, a speaker might signify to elicit humor and laughter among acquaintances. Depending on the context and environment, this language play is written using vernacular spellings or pronunciations. When the - $g$ is dropped, the term is known as either signifyin' or siggin.' Additionally, signifying might have altogether different names. Depending on the region or time period, verbal signifying might be called joanin, riffi n', reading, or sounding. The act of signifying not only manifests in African and African American oral culture but also in African American literature (Robinson).

Moreover, Robinson talks about how Gates insists that the critics of the literature of the black must be aware of the comparative aspect underlying these works of art:

Black critics must always be comparativists because, free of the white man's gaze, black people created their own unique vernacular structures using repetition and revision, which are fundamental to the black artistic forms. As he puts it, "Whatever is black about black American literature is to be found in this identifiable black Signifyin(g) difference" (Robinson).

In order to fully understand the differences mentioned above, Gates refers to the double-consciousness inherent in Black culture,

To identify these differences, Gates goes on to discuss the black tradition being double voiced and identifies four versions of doublevoiced textual relations: tropological revision, the speakerly text, the talking text, and rewriting the speakerly. Tropological revision is a trope that is repeated (and revised) from text to text. Examples of these tropes include the protagonist's descent underground, the vertical ascent from South to North, and figures of the double, including double consciousness (Robinson).

The tropological aspect mentioned here is closely related to the one mentioned by Brian McHale. In Wilson's plays we observe the use of metaphors and games of language which nicely convey the idea of signifying, speaking in an indirect form and revising and rewriting some elements which exist in each play. The settings of each play, their atmosphere, their sense of spirituality and community all serve to present the notion of the African-American life and how their doubleconsciousness influences their decisions.

A number of critics have opposed Gates' poststructuralist views toward Black works of art, such as Joyce A. Joyce who maintains, that post structural theory is irrelevant for black literature because it divides the signifier of race from the signified of racial discrimination and oppression, turning the former into mere metaphor operating in the abstracted worlds of literary and cultural production. This turns race into more of a linguistic puzzle that black literary scholars try to solve in discourse. She regards this as at best an unintentional evasion of the political imperatives of black literature and pedagogy, and an outright rejection of that responsibility at worst [4].

\section{Discussion}

Seven Guitars is a play about a man with high ambitions for music. A play about identity, love, death and how they all intertwine. At the beginning of the play we are informed that Floyd is dead and the characters are back from his funeral. We have several characters. Vera, Floyds beloved, who owns the apartment in the yard of which the play is set. Louise and Hedley, the two tenants who live on the second floor. Hedley owns some chickens and turkeys and usually beheads them on his table in the yard. We have Red Carter, Floyd and Vera's friend and Canewell, Vera's former lover. Scene one of act one revolves around the death of Floyd and how all the characters except Louise have witnessed angels taking Floyds body to the sky. From the very beginning we observe the spirituality present in their lives. In scene two we have a flashback to when Floyd was alive. This aspect of the play has been said to be an influence of Luis Borges. Giving the ending of the play and unwinding what has led to this conclusion is a Borgesean characteristic. As Harry Elam explains, the main action of the play concerns flashbacks to times when Barton was alive. Consequently, the real movement of the play has already occurred, back in the past, before the opening scene. The play literally progresses forward by going backward [5].

Furthermore, another postmodern element is detected from Wilson's own words,

Some things may appear to be extraneous to the plot line ... But if you start pulling things away, you take away the field of manners and ritual intercourse. All of the things in the play are very necessary, but they all appear to be quite unnecessary. If you take something out, the structure will fall down (qtd in Murphy).

The fact that the plot may seem confusing yet it being deliberately made this way by Wilson himself implies the postmodern tendency to complicate the reader's understanding of the story. During the plays, the reader must follow the story of each character to fully grasp the ancestral, mythical and spiritual backgrounds which stem from the characters from the very beginning (Gem of the Ocean) to the end of the cycle (Radio Golf).

In scene two we become familiar with the relationship between Floyd and Vera. The fact that Floyd is obsessed with becoming a musician and counts on the contract he thinks is waiting for him in Chicago. Vera has been abandoned once already by Floyd and is reluctant to do so, again as Floyd insists she must go with him to Chicago.

The society and social conditions of the 1940s is highlighted in Seven Guitars. In these years there was another migration which led to shifts in cultural and social lives especially music. As Gabriel Stepto explains [6],

The Second Great Migration from the Mississippi Delta to Chicago in the 1940s produced a new blues form, known as Chicago blues, native to the industrial city. Muddy Waters (1915-1983) became the leading innovator of the new style after he reached Chicago in 1943. Muddy Waters and his contemporaries-among them Big Bill Broonzy (1893-1958), Howlin' Wolf (1910-1975), Jimmy Rogers, B. B. King (b. 1925), Bobby Blue Bland (b. 1930), John Lee Hooker (1917-2001), J.B. Lenoir, and Willie Dixon (1915-1992)-had been trained in the country style of acoustic guitars and solo performance [6].

This is why Floyd insists so much on going there and taking Vera with him. He tells Vera: 
Floyd: Wait till you see it. There ain't nothing like it. They got more people than you ever seen. You can't even imagine that many people. Seem like everybody in the world in Chicago. That's the only place for a black man to be. That's where I saw Muddy Waters. I was walking past this club and I heard this music. People was pushing and crowding in the club. Seem like the place was busting at the seams. I asked somebody, I say, "Who's that?" They told me, "That's Muddy Waters". I took off my hat. I didn't know you could make music like that. That told me say, "The sky's the limit". I told myself say, "I'm gonna play like that one day". I stayed there until they put me out. Mr. T. L. Hall asked me what I wanted to do. I told him I wanted to play at the Hurricane Club. He says he'd fix it (SG 23).

Floyd is very determined to reach his goals yet fails to do so. As Harry Elam posits, "Floyd 'Schoolboy' Barton's story is reminiscent of the tragic myths and legends of larger-than-life black bluesmen" (Elam). Floyd's situation is closely related to Levee's hope of Sturdyvant's help with his music recording. Both men put faith in the wrong person.

Scene three starts with Hedley's chicken killing. He has his tools ready and goes back and forth into the basement where he keeps his chickens. The atmosphere of the play is very intense when Hedley is involved. Harry J. Elam notes that, "In Wilson's work it is the characters that appear mentally or physically impaired, besieged by madness, unable to grasp the reality of the world around them, who represent a connection to a powerful, transgressive spirituality, to a lost African consciousness and to a legacy of black social activism" (qtd. in Herrington). The stage directions and narrations tell from the beginning that a rooster is constantly crowing in the background. There have been a lot of interpretations regarding the symbol of a crowing rooster. As for the symbolic significance of the cock-crow,

The most famous cock-crow in the Bible is the one Jesus predicts will end the night in which Peter betrays him: "this night, before the cock crow, thou shalt deny me thrice" (Matt 26.34); just when Peter denies for the third time that he knew Jesus, "immediately the cock crew" and Peter "wept bitterly" (Ferber).

This religious notion is the same as the one Aunt Ester exemplifies for Citizen Barlow on his journey to the city of bones. She tells him how Peter denied Christ three times and how he should not hope to be lucky like him. He might not get another chance. He should confess at once. We can hear Aunt Ester even though she does not physically appear in Seven Guitars. Hedley's rooster killing, after all the fuss the characters make over is sound in the neighborhood, shows the loss of roots as elaborated by Murphy,

Hedley performs a ritual, scattering the rooster's blood in a circle and then throwing the rooster on the ground, saying, 'this rooster too good live for your black asses' (64). This ritual killing severs the connection between the urban black community in this Pittsburgh back yard and its rural southern roots, reaching back further through the West Indian and African traditions on which Hedley is drawing (Murphy).

Hedley is the character who, like Bynum in Joe Turner, believes in the spiritual power of mankind. Louise believes Hedley is sick and must see a doctor; however, Hedley has his own remedies:

Louise: You need to go see the doctor. You be spitting up blood. That don't sound like no job for Miss Sarah. You go to see Miss Sarah when you have a cold. You need to go back to that doctor and do what they tell you. They got medicine they can give you. That's what happened to
George Butler. He didn't go back to the doctor. You need to get another chest X-ray. Miss Sarah can't do that.

Hedley: Miss Sarah a saint. She a saint if ever God made one. She can heal anything. She got a big power. She got her roots. She got her teas. She got her powders...(SG 31).

Hedley's dialogue brings the notion of roots and origins to mind. When one has his/her roots, one can heal any wound. Perhaps Miss Sarah reminds one of Aunt Ester and her healing powers. Wilson manifests the idea of roots with the character of Hedley and his idols such as Toussaint L'Ouverture, the rebel leader of the slave revolt on the French colony of Saint-Domingue (Michael J. Drexler and Ed White 59). Hedley is the warrior who is self-empowered. With his constant references to historical personages and biblical characters and sermons, he gains the power to rebel against the dominant believes of the time $[7,8]$.

Again, the issue of naming brings about important notions in Seven Guitars too. The most obvious would have to be Canewell as he explains himself:

\section{Canewell: You ought to put you in some sugarcane.}

\section{Hedley: No. No sugar. I hate the sugar. Sugar beat many a man.}

Canewell: That's how I got my name. My granddaddy used to cut sugarcane in Louisiana. Somebody seen him say, "That boy can cane well." Otherwise my name would be Cottonwell (SG 36-37).

Moreover, when Floyd, Red Carter, Hedley and Canewell are in the yard speaking about the name of Red Carter's boy, we witness the role of naming in the African-American world,

\section{Canewell: Red Carter got a baby boy.}

Hedley: I hope he grow up and be big and strong like Joe Louis. Maybe one day I too have a son.

Canewell: Joe Louis fighting tonight. We're gonna listen to it on the radio.

\section{Floyd: What you name him Red?}

Red Carter: I ain't had the chance to name him nothing. She naming him Mister.

Canewell: White folks gonna have a fit with a nigger named Mister. Mr. Mister Carter. (SG 51)

African-Americans are not only marginalized because of their skin color but also because of their language. In Seven Guitars we witness the lives of characters who speak in a vernacular which gives them their social status. As Debose explains, "The superior position of the dominant group is justified by their "proper" speech; and the subordinate position of marginalized groups is legitimated by the characterization of their language'. However, this feature of Black culture is celebrated in Seven Guitars, as well as in the other plays of Wilson's century cycle. Wilson highlights the importance of Black vernacular in the lives of the oppressed. This language is what keeps them African and American at the same time. By fashioning themselves with their language they enter the society and pass the margins. Seven Guitars is about a group of friends who gather in the back yard of a house to either drink, play cards or dance. Their interactions evidently demonstrate their Black personality. A part in the play where Louise indicates the notion of "signifying" interestingly highlights this issue $[9,10]$ : 
Hedley: It's gonna be a big plantation.

Floyd: I just want to come and sit on your front porch and drink mint juleps.

\section{Louise: Look at Floyd signifying.}

Floyd: The man says he gonna get him a plantation. I ain't gonna be the one who tell him no. Somebody else gonna have to do that. If I see where he gets his that might make me want to get one too (SG 37).

What Floyd is doing is what Gates described as the characteristic of the trickster figure (the Signifying Monkey). As he posits, the trickster figure is one who lies, cajoles, imitates and parodies. This is what Floyd does, he agrees with Hedley yet at the same time we know he does not care for what Hedley really thinks. Louise understands that he is lying and accuses Floyd of signifying. In Abrahams' terms, "Signifying seems to be a Negro term, in use if not in origin. It can mean any of a number of things; in the case of the toast about the signifying monkey, it certainly refers to the trickster's ability to talk with great innuendo, to carp, cajole, needle, and lie" (qtd in Gates). The scene well exemplifies this definition.

In Addition, we have songs Floyd, Canewell and Red Carter sing with each other that effectively convey the action of signifying too:

Canewell: "In days of old when knights was bold.

And paper wasn't invented.

They wiped their ass on a blade of grass.

Floyd and Canewell: And walked away contented.

Canewell: But do you know this one?

"Ladies and gentlemen I stand before you.

To sit behind you,

To tell you something,

I know nothing about".

Floyd: "The admission is free. You pay at the door. There's plenty of seats. You sit on the floor".

Canewell: "There's room for ladies. But only men can go. And that's about all I know"

Floyd and Canewell: We're gonna discuss the four corners of the round table!"

Floyd: That always lay me out.

Red Carter: "One bright morning in the middle of the night two dead boys got up to fight.

Back to back they faced each other.

Drew their swords and shot each other.

A deaf policeman heard the noise.

And came and killed those two dead boys".

Canewell: "Watermelons sweet and green. Best watermelons you ever seen. You eat the meat and pickle the rind. Save the seed till planting time" (SG 48-49).

This demonstration of a song is language in the form of music. It juxtaposes the most important feature of Black culture, their music, with another key element which is language. This passage highlights the notion of signifying and what Debose calls "copula deletion". According to Debose, ' One of the most intensely studied grammatical features of African-American language, known as copula deletion' (Labov 1969)...is marked by the frequent absence of present tense forms'. For example, 'The man say he gonna... instead of, 'The man says he is going to...'. Such sentence deletions are recurrent in Black language which makes their language unique and Black. The predominant view towards Black vernacular is that it is not English or it is 'bad English'. It is not grammatical hence it is not English at all. However, Seven Guitars and other plays by Wilson show how this uniqueness is in itself totally grammatical and ok in Black vernacular $[3,11,12]$.

\section{Conclusion}

These songs both convey a meaning and do not at the same time. They are full of paradoxes, a key word in historiographic metafiction. To state something and at the same time question that very concept. Another notion in the play that takes us back to the roots and origins of the African-American is when Canewell brings Vera a goldenseal plant. According to him and Hedley it is a healing plant. One used by their ancestors. Vera and Hedley plant it in the yard with its roots not too deep. A plant represents life. If a plant is taken care of, it will grow bigger and stronger. Later we see the exact act in King Hedley II to which Seven Guitars is a sequel. Yet again the play ends in the tragic death of Floyd by the hands of Hedley, another Black on Black crime, and another sacrifice for self-recognition. By 'signifying,' repeating, revising, the African-American both entertains and revolts against a standard white language. By using English in this way, the AfricanAmerican fashions his/her own identity. The Black vernacular can be seen as a way of gaining uniqueness in the center of a white American culture. Wilson's representation of this language is truly unique too.

\section{References}

1. Kjelle MM (2004) African-American leaders: Henry Louis gates. Chelsea House.

2. Abrams $\mathrm{MH}$ (2005) A glossary of literary terms. Wadsworth Cengage Learning.

3. Wilson A (2007) Seven Guitars. Theatre Communications Group publishing, New York.

4. James MS (2011) Icons of African American literature. Greenwood, California.

5. Harry JE, Wilson A, David K (2004) A companion to twentieth century American drama. Blackwell, Malden.

6. Stepto GB (2003) The African American Years. The Gale Group, New York.

7. DuBois WEB (1997) The Souls of Black Folk. Boston.

8. Michael F (2007) The dictionary of literary symbols. Cambridge University Press, Cambridge.

9. Charles D (2005) The sociology of African-American language-a language planning perspective. Palgrave Macmillan, New York.

10. Henry Louis JG (2004) The blackness of blackness: a critique on the sign and the signifying monkey. In: Julie Rivkin R, Michael (eds.), Literary theory: an anthology. Blackwell.

11. Brenda M (2007) The tragedy of seven guitars. In: Christopher B (ed.), Cambridge companion to August Wilson. Cambridge University Press, Cambridge.

12. MacHale B (1987) Postmodernist Fiction. Methuen, New York. 